\title{
Ethno-demographic position of Serb population in Republic of Slovenia after the dissolution of former Yugoslavia
}

\author{
Irena Medar-Tanjga \\ University of Banja Luka \\ 2 Mladena Stojanovića, Banja Luka, 78000, Bosnia and Herzegovina, Republic of Srpska
}

\begin{abstract}
The problem of Serb population in Republic of Slovenia is a paradigm of all the problems that have arisen with the dissolution of the Socialist Federal Republic of Yugoslavia. Political and geographic processes during this disintegration led to the creation of new political and territorial subjectivities, with significantly changed conditions of ethno-cultural and ethno-demographic development. Serbs who lived in the same country now are living in Diaspora with limiting institutional framework of development. The contemporary ethno-demographic position of Serbs in Slovenia is conditioned by numerous regional (Balkan) and local determinants. The number of Serbs, territorial arrangement, their awareness of ethnic affiliation, mutual relations within the community, relations with the country in which they live, relations with the states they came from, all together with the influences of surroundings, are essential elements of their position in Slovenia. This position was different in different historical epochs and required different forms of action to preserve the ethnic identity of this community. Serbs in Slovenia went from constituency and equality to ignorance and eradication, they have not been officially recognized as minority, although the existence of an indigenous community in Bela Krajina presents a historical basis for their better status. Minority status is very important, although for the preservation and development of national and cultural identity is not decisive. Namely, apart from legal regulations, stable and favorable social and political circumstances are needed to preserve the identity of each minority.
\end{abstract}

Keywords: Serb population, Republic of Slovenia, ethno-demographic position, population, geographic distribution, status

\section{Introduction}

With the collapse of the former Yugoslavia as joint state and by forming the Republic of Slovenia, status of the Serb population has been radically changed (Klopčič, Komac, Kržišnik-Bukić, 2003). Members of the constituent nations of Yugoslavia who, for the most part, have been migrated because of employment in another part of the still common homeland (Komac, 2007), practically overnight became a statistically established minority with all the attributes of economic immigrant groups (Комац, 2000). Serbs in Slovenia do not have the official status of a national minority. Serbian entity does not exist in formal or legal sense for the Republic of Slovenia.

The results of the population censuses provide a data from which the conclusions of the Serbs in Slovenia are drawn. Number of Serb population, their percentage of the total population of Slovenia, geographic distribution, migration, religion traits form a framework of quantitative and qualitative characteristics, indicating status of the Serbs in the Slovenia. 


\section{Literature review}

The basic data on the number and geographic distribution of Serbs in Slovenia can be found in the publications of the Statistical Office of the Republic of Slovenia. The most comprehensive analysis at all levels of governmental organization of the state can be found in the publication "Religious, linguistic and ethnical composition of the population of the Republic of Slovenia. 1921-2002 censuses" (Šircelj, 2003). In the year 2011 the Statistical Office of the Republic of Slovenia conducted register-based census by using the Central Population Register and the Real Estate Register, thus not providing information on the ethnical composition of the population. In addition to the contemporary state it is necessary to inspect the status of the Serbs from the moment of immigration to the Bela Krajina territory in the $16^{\text {th }}$ century (Ивић, 1923; Мал, 1924; Filipović, 1970).

In response to the Serbs status in Slovenia after the dissolution of former Yugoslavia, a scientific conference was held in 1996 in Sremski Karlovci (Serbia), from which the problems were presented from different perspectives. Researchers in the Republic of Slovenia also conducted several major researches on the status of new minority groups. The results were published in the followed publications: Albanians, Bosnians, Montenegrins, Croats, Macedonians and Serbs in the Republic of Slovenia (Klopčič, Komac, KržišnikBukić, 2003), Migrants - studies on immigration and inclusion in the Slovenian society (Komac, 2007), Perception of Slovenian Integration Policy (Komac, Medvešek, 2005) and Perceptions of Slovenian Integration Policies - "Uskok" population in Bela Krajina, ethnic discrimination in the working environment, emigration and returnees of Slovenes (Komac, Medvešek, 2006).

Activities for obtaining the minority status as well as the relation with the country of origin to the expelled population are issues that have been observed at the level of state organizations of the Republic of Serbia and Republic of Srpska (Bosnia and Herzegovina). As a basic source of information, the websites of state institutions has been used. Continuous monitoring provided data on the activities related to the emigrants.

\section{Methods}

The methodological approach and research methods are tailored to the tasks and to the research goal. Considering the complexity of the problem, the interdisciplinary approach is dominant. To a full extent, methods of analysis, synthesis, comparison, historical, cartographic, demographic method, inductive and deductive research method will be used. Based on the historical, geopolitical, cultural and legal position, the problem of Serbs development in Slovenia will be pointed out. Field research and cabinet work are the basic techniques applied in the methodological process.

\section{Biological dynamics of Serb population in Slovenia}

The Republic of Slovenia from its formation in the 1990s until today can be classified as a country whose population is ethnically homogeneous (over $80 \%$ of the population is a one ethnic group). The number of Serbs, its incidence in the total population, their geographic distribution, economic and political power has changed during different historical periods (Šircelj, 2003). 
Медарь-Танга И. Вестник РУДН. Серия: Экономика.

2018. T. 26. № 4. С. $674-684$

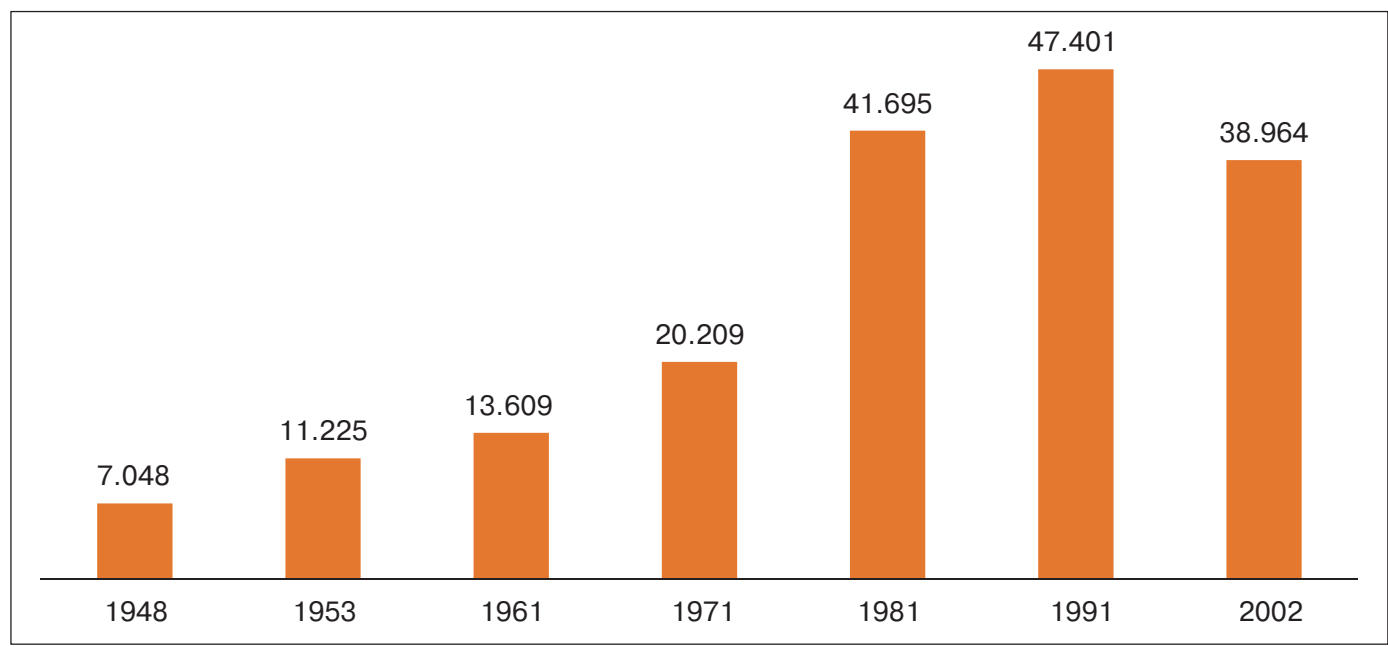

Figure 1. Number of Serbs in Slovenia, 1948-2002 censuses

Source: Statistical Office of the Republic of Slovenia

Table 1

Population by ethnic affiliation in Slovenia (percentage participation), 1948-2002 censuses

\begin{tabular}{|c|c|c|c|c|c|c|c|}
\hline Ethnic affiliation & 1948 & 1953 & 1961 & $1971^{1}$ & $1981^{1}$ & $1991^{1}$ & 2002 \\
\hline \multicolumn{8}{|l|}{ Declared } \\
\hline Slovenes & 97.00 & 96.52 & 95.65 & 94.04 & 90.77 & 88.31 & 83.06 \\
\hline Italians & 010 & 0.06 & 0.19 & 0.18 & 0.12 & 0.15 & 0.11 \\
\hline Hungarians & 0.76 & 0.75 & 0.66 & 0.53 & 0.48 & 0.42 & 0.32 \\
\hline Roma & 0.00 & 0.12 & 0.01 & 0.06 & 0.08 & 0.12 & 0.17 \\
\hline Albanians & 0.02 & 0.01 & 0.02 & 0.08 & 0.11 & 0.18 & 0.31 \\
\hline Austrians & 0.04 & 0.02 & 0.02 & 0.02 & 0.01 & 0.01 & 0.01 \\
\hline Bosniacs $^{2}$ & $\ldots$ & $\ldots$ & $\ldots$ & $\ldots$ & $\ldots$ & $\ldots$ & 1.10 \\
\hline Bulgarians & 0.00 & 0.00 & 0.01 & 0.01 & 0.01 & 0.01 & 0.01 \\
\hline Vlachs & $\ldots$ & 0.00 & 0.00 & 0.00 & 0.00 & 0.00 & 0.00 \\
\hline Greeks & 0.00 & 0.00 & 0.00 & 0.00 & 0.00 & 0.00 & 0.00 \\
\hline Jews & 0.00 & 0.00 & 0.00 & 0.00 & 0.00 & 0.00 & 0.00 \\
\hline Macedonians & 0.03 & 0.04 & 0.06 & 0.09 & 0.18 & 0.23 & 0.20 \\
\hline Muslims $^{3}$ & $\ldots$ & 0.11 & 0.03 & 0.19 & 0.73 & 1.39 & 0.53 \\
\hline Germans & 0.13 & 0.11 & 0.05 & 0.02 & 0.02 & 0.02 & 0.03 \\
\hline Poles & 0.03 & 0.02 & 0.01 & 0.01 & 0.01 & 0.01 & 0.01 \\
\hline Romanians & 0.01 & 0.00 & 0.00 & 0.00 & 0.01 & 0.01 & 0.01 \\
\hline Russians & 0.06 & 0.04 & 0.02 & 0.02 & 0.01 & 0.01 & 0.02 \\
\hline Russinians ${ }^{4}$ & 0.01 & 0.00 & 0.02 & 0.00 & 0.00 & 0.00 & 0.00 \\
\hline Slovaks & 0.01 & 0.01 & 0.00 & 0.00 & 0.01 & 0.01 & 0.01 \\
\hline Serbs & 0.51 & 0.77 & 0.86 & 1.20 & 2.27 & 2.48 & 1.98 \\
\hline Turks & 0.00 & 0.01 & 0.01 & 0.00 & 0.00 & 0.01 & 0.01 \\
\hline Ukrainians $^{4}$ & $\ldots$ & $\ldots$ & $\ldots$ & 0.01 & 0.01 & 0.01 & 0.02 \\
\hline Croats & 1.15 & 1.23 & 1.97 & 2.47 & 2.93 & 2.76 & 1.81 \\
\hline Montenegrins & 0.04 & 0.09 & 0.09 & 0.12 & 0.17 & 0.23 & 0.14 \\
\hline Czechs & 0.08 & 0.06 & 0.04 & 0.03 & 0.02 & 0.02 & 0.01 \\
\hline Others declared & 0.02 & 0.02 & 0.03 & 0.02 & 0.03 & 0.05 & 0.08 \\
\hline
\end{tabular}




\begin{tabular}{|c|c|c|c|c|c|c|c|}
\hline Ethnic affiliation & 1948 & 1953 & 1961 & $1971^{1}$ & $1981^{1}$ & $1991^{1}$ & 2002 \\
\hline \multicolumn{8}{|l|}{ Undeclared } \\
\hline Declared as Yugoslavs & - & - & 0.18 & 0.39 & 1.39 & 0.63 & 0.03 \\
\hline Declared as Bosnians ${ }^{5}$ & $\ldots$ & $\ldots$ & $\ldots$ & $\ldots$ & $\ldots$ & $\ldots$ & 0.41 \\
\hline Regionally declared & - & - & - & 0.16 & 0.21 & 0.27 & 0.07 \\
\hline Others undeclared $^{6}$ & - & - & - & 0.18 & 0.16 & 0.46 & 0.62 \\
\hline Did not want to replay & $\ldots$ & $\ldots$ & $\ldots$ & $\ldots$ & $\ldots$ & $\ldots$ & 2.47 \\
\hline Unknown & 0.00 & 0.01 & 0.07 & 0.16 & 0.29 & 2.21 & 6.43 \\
\hline Total & 1.391 .873 & 1.466 .425 & 1.591 .523 & 1.679 .051 & 1.838 .381 & 1.913.355 & 1.964 .036 \\
\hline
\end{tabular}

Source: Statistical Office of the Republic of Slovenia.

\section{Remarks:}

1. Data recalculated according to the 2002 Census methodology. So called "migrant workers" are covered. At 1948, 1953 and 1961 censuses the category of "migrant workers" did not exist.

2. Declaration for a Bosniak as a nation was enforced by the Constitution of the Federation of Bosnia and Herzegovina in 1994.

3. Including persons who said they were Muslims in the sense of ethnic and not religious affiliation.

4. In 1953 and 1961 censuses the Russinians and the Ukrainians appears under one item.

5. In previous censuses people who said they are Bosnians were included in the item regionally declared.

6 . Including persons who said they would like to remain ethnically undeclared.

Between 1948 and 1991, the number of Serbs was steadily increased. The largest increase of the Serb population was recorded between the censuses in 1971 and 1981 . During this period, economic immigrants came to Slovenia, mostly as an unskilled labor force, which were needed to maintain a developed Slovenian economy. Serbs from Bosnia and Herzegovina were dominant among Serb immigrant population, followed by Serbs from Serbia and Montenegro. In 1991, Serbs in Slovenia recorded their maximum.

Changes in state borders during the process of the Slovenia's independence in 1991 led to a change in the ethnical composition of the population. Some members of nonSlovenian ethnicities left Slovenia. The number of Serbs, as well as their participation in the total population of Slovenia, has decreased.

\section{Geographic distribution of Serb population in Slovenia}

The ways of Serbs settlement in Slovenia has determined their basic characteristic: spatial dispersion, so that Serbs can be found in all municipalities of Slovenia. Geographic distribution, along with other processes and relations, is the main reason that there was no internal homogenization of the Serbian population, or to the wider manifestation of its ethnic identity in relation to the majority people.

Table 2

Percentage of Serb population in statistical regions of Slovenia, 1991 and 2002 censuses

\begin{tabular}{|c|c|c|}
\hline Statistical Region & 1991 & 2002 \\
\hline Mura & 0.27 & 0.19 \\
\hline Drava & 1.16 & 0.81 \\
\hline Carinthia & 1.14 & 0.77 \\
\hline Savinja & 1.86 & 1.68 \\
\hline
\end{tabular}




\begin{tabular}{|l|r|c|}
\hline \multicolumn{1}{c|}{ Statistical Region } & 1991 & 2002 \\
\hline Central Sava & 2.03 & 1.80 \\
\hline Lower Sava & 0.97 & 0.62 \\
\hline Southeast Slovenia & 1.69 & 1.21 \\
\hline Central Slovenia & 4.36 & 3.38 \\
\hline Upper Carniola & 3.36 & 2.89 \\
\hline Inner Carniola-Karst & 3.27 & 2.81 \\
\hline Gorizia & 1.71 & 1.46 \\
\hline Coastal-Karst & 3.63 & 3.10 \\
\hline Slovenia & 2.48 & 1.98 \\
\hline
\end{tabular}

Source: Statistical Office of the Republic of Slovenia

According to the 1991 Census, Serbs accounted for $2.48 \%$ of the total population of Slovenia. Over $4 \%$ were in Central and more than $3 \%$ in the Upper Carniola and Inner Carniola-Karst statistical regions, while the least were represented in Mura $(0.27 \%)$ and Lower Sava (0.97\%) statistical regions. According to the 2002 Census, Serbs accounted for $1.98 \%$ of the total population of Slovenia. In Central Slovenia, Coastal-Karst, Upper Carniola and Inner Carniola-Karst statistical regions, about $3 \%$ of the population was taught. They were least represented in the Mura Statistical Region with $0.19 \%$.

Both censuses include a significant percentage of the population who did not want to declare their ethnicity, as well as those who declared themselves as Yugoslavs or regionally declared. It is to be assumed that there was a significant number of Serb population among these population, but also those in mixed marriages as well as their descendants. They did not want to express their ethnicity either before or after the independence of Slovenia, or they did not wish to declare for the state from which they originate, or for the country in which they are currently living.

Table 3

Municipalities with the largest number of Serbs, 1991 and 2002 censuses

\begin{tabular}{|l|c|c|c|c|}
\hline \multirow{2}{*}{ Municipality } & \multicolumn{2}{|c|}{1991} & \multicolumn{2}{c|}{2002} \\
\cline { 2 - 5 } & Number & $\%$ & Number & \% \\
\hline Ljubljana & 17.003 & 35.5 & 13.101 & 33.6 \\
\hline Maribor & 2.980 & 6.2 & 2.049 & 5.3 \\
\hline Kranj & 2.758 & 5.8 & 2.744 & 7.0 \\
\hline Koper & 1.940 & 4.0 & 1.693 & 4.3 \\
\hline Celje & 1.939 & 4.0 & 1.733 & 4.4 \\
\hline Jesenice & 1.665 & 3.5 & 1.347 & 3.5 \\
\hline Velenje & 1.546 & 3.2 & 1.508 & 3.9 \\
\hline Nova Gorica & 1.064 & 2.2 & 856 & 2.2 \\
\hline Postojna & 1.049 & 2.2 & 858 & 2.2 \\
\hline Novo Mesto & 1.047 & 2.2 & 694 & 1.8 \\
\hline Rest & 14.920 & 31.2 & 12.381 & 31.8 \\
\hline Slovenia & 47.911 & 100 & 38.964 & 100 \\
\hline
\end{tabular}

Source: Statistical Office of the Republic of Slovenia. 
Serbs are most represented in 72 municipalities, with a relatively low rate of concentration of population, although nearly a third of them live in capital of Slovenia, Ljubljana. They settled mostly in the towns and therefore they are least in the municipalities of northeastern Slovenia and on the border with the Republic of Croatia. Most of them inhabited municipalities in central and western Slovenia, where they represent the majority of the migratory population. More than $5 \%$ of the population is in the settlements along the Ljubljana-Koper railways as well as in some of the larger settlements of Upper Carniola Statistical Region.

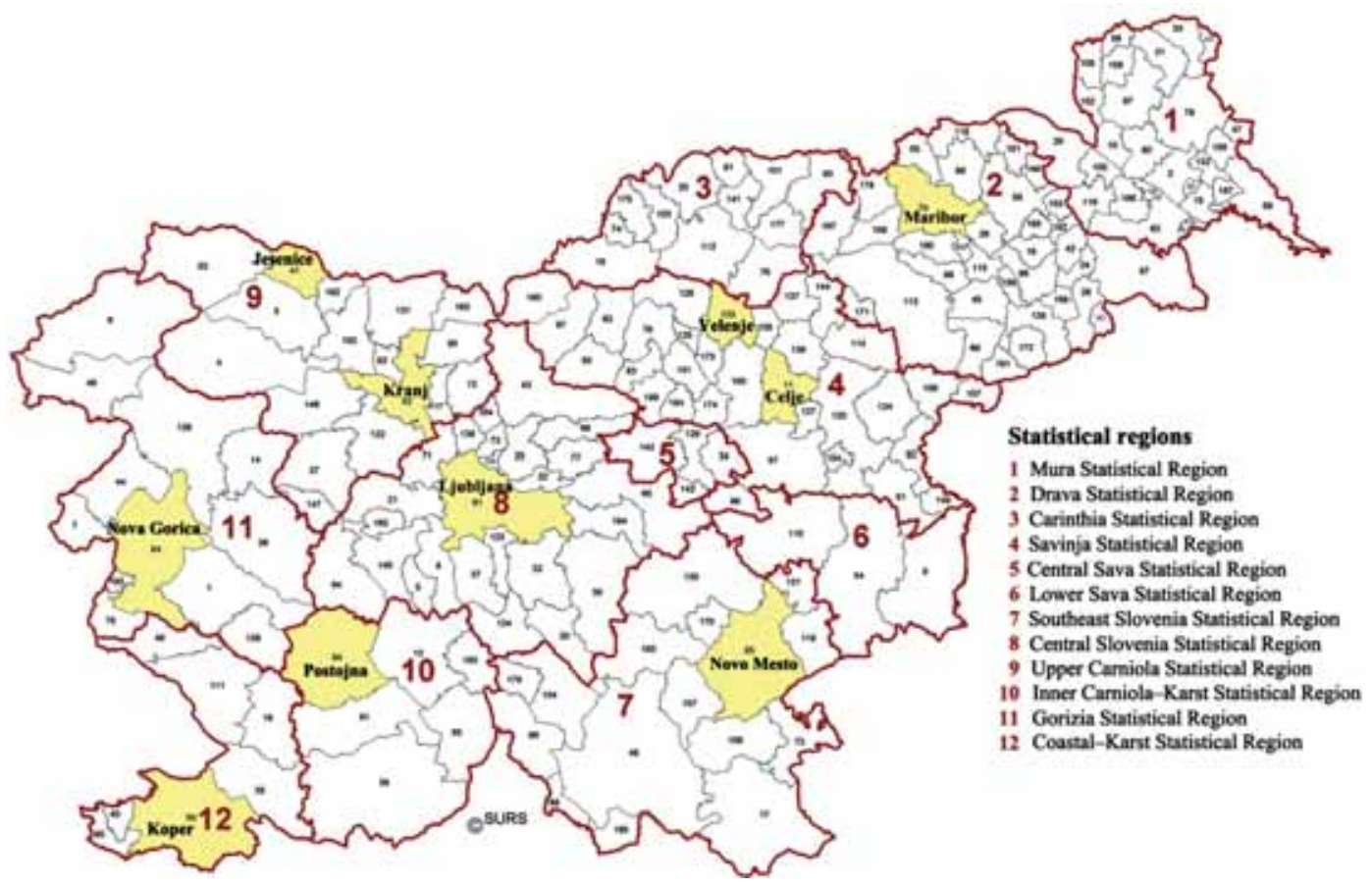

Figure 2. Municipalities where the largest number of Serbs lives

According to data from 1991 to 2002 censuses, the number of Serb population decreased by $17 \%$. The number of Serbs has increased in 23 municipalities. In 26 municipalities the number of Serbs remained unchanged. In 32 municipalities the number of Serbs decreased considerably. Most of them decreased in Ljubljana, in almost all of eastern Slovenia, and in the cities where the former Yugoslav Army was stationated.

\section{Political-legal and social position of Serb population in Slovenia}

After obtaining independence, the Republic of Slovenia adopted a policy that implies a different legal status of indigenous and "new" minorities. The unequal legal position in many places also their unequal factual position.

Estimating that the votes of Hungary and Italy will be required in order to join the European Union, Slovenia granted the status of minority to the Hungarians and Italians (Kristen, 2004; Žagar, 2006; Komac, 2007; Roter, 2008). It should be noted that these groups have already had this status in the former joint state. Other constituent nationalities 
of the former Yugoslavia do not get the status of minority. The total number of members of these two minorities is about $8.500(0.43 \%)$, while the "new" minorities make up about 130.000 (6.10\%) members. Besides Serbs there are Montenegrins, Croats, Bosnians, Muslims, Macedonians and Albanians in this group. Most of them had a permanent residency and employment in Slovenia, but were citizens of other Yugoslav republics (Komac, 2007; Bešter, 2009; Komac, Medvešek, 2005).

If the fact that the legislator has made a distinction between indigenous and "new" minorities is ignored, which present a serious barrier to equal treatment of these groups, it remains unclear why indigenous groups, such as Serbs in Bela-Krajina, are beyond the reach of their rights (Kopah, 2005; Komac, 2007; Komac, Medvešek, 2006). The fact that they are small community is not an obstacle to the recognition of special rights, because they are just indispensable for such communities to preserve their identity (Башић, 2005; Medvešek, Bezigar, Bešter, 2009).

The right to education in minority languages is realized only by indigenous minorities, as regulated by the Act Regulating Special Rights of Members of the Italian and Hungarian Ethnic Communities in the Field of Education. In addition, all students in Slovenia are familiar with the characteristics and particularities of language, culture and history of national minorities during their schooling.

Education of "new" minorities includes free compulsory education of their children within the Slovenian school system and the optional right to supplementary mother language education, which is guaranteed by the Elementary School Act. Parents and children opt for this independently, and it is planned to spend 3-5 hours each week (Башић Г., 2005). Although the Law foresees the possibility of optional teaching of mother language, there are no classes in the Serbian language.

\section{Serbs demands for the minority status}

In September of 2004 the Ministry of Diaspora of the Republic of Serbia sent a request for recognition of minority status to the Serbs in Slovenia to the Republic of Slovenia. The letter referred to the Serbs, who had permanent residence in Slovenia before the dissolution of Yugoslavia. The Serbian Ministry considers that the Serb population is the most numerous in Slovenia, and therefore Slovenia should recognize international standards for its protection.

Serbs' desire for minority status is understandable for two reasons. The fact is that Serbs are also an indigenous people of Slovenia (Janko Spreizer, 2006, Komac, Medvešek, 2006), as thousands of people live for several centuries in the territory of Bela Krajina (Ивић, 1923; Мал, 1924; Filipović, 1970). The second reason lies in the fact that in 2002 Census, Serbs are the most numerous immigrant ethnical group, with almost 40.000 members (2\%). One of the most important wishes of the signatory of the Serbian Ministry of Diaspora document is the possibility of education of Serbs in their mother language.

Following this initiative, Serbs in Slovenia have repeatedly submitted requests for obtaining the minority status to various authorities in Slovenia. The status is still unchanged, i.e., the response from the Slovene officials was negative with the most common explanation that "there was still no time for such changes". 
Serbs in Slovenia think that in order to solve this problem, it is necessary to get help of the institutions from Republic of Serbia and Republic of Srpska (Bosnia and Herzegovina). Bilateral agreements between Slovenia and the other two states can regulate the status of Serbs in Slovenia and that the reciprocity system can improve their status. Since Slovenians in Serbia and in the Republic of Srpska (Bosnia and Herzegovina) have minority status, it is also obligation of the authorities of these states, to provide the same position to their Diaspora.

\section{Conclusions}

Republic of Serbia and Republic of Srpska (Bosnia and Herzegovina) should definitely take decisive role in improving living conditions and preserving the national identity of their Diaspora (Становчић B., 2005). Serbia has formed Ministry of Diaspora in 2004. Ministry of Diaspora issued the Law on the Diaspora and Serbs of the Region in 2009, the Strategy for maintaining and strengthening relations between the home country and Diaspora as well as between the home country and Serbs in the region in 2011. In the Law on the Diaspora and Serbs of the Region, the idea of "Serbs in the region" was introduced in the attempt to make an objective point of view on situation in the former Yugoslav republics. The Ministry of Diaspora was abolished and in 2012 the Office for Cooperation with Diaspora and Serbs in the Region was established. In the 2014 the Office was abolished and the Directorate for Cooperation with the Diaspora and Serbs in the Region within the Ministry of Foreign Affairs was formed. Frequent changes in competencies, with the abolition of jurisdiction at lower levels of state administration, do not support the engagement of the home country in the way of improving the status of the Diaspora. The activities of the home country are mainly reduced to the financing of projects of the Diaspora and Serbs in the Region which are aimed to contribute to the preservation and strengthening of the relations between the home country and the Diaspora and Serbs in the Region. Project are aimed to the organization of education of children and youth, the creation and procurement of books, organization of cultural and sporting events, while the essential issues of a better status of Serb population in the countries in which they live continue to remain a side ${ }^{1}$.

The situation in Bosnia and Herzegovina, where a significant part of the Serb population in Slovenia comes from, is even worse than in Serbia. Apart from the absence of the Ministry for Diaspora (the Sector for Diaspora at the Ministry for Human Rights and Refugees in the Council of Ministers are in charge for Diaspora issues), the basic problem in Bosnia and Herzegovina is the division of the entities and the existence of three constituent nations of this state ${ }^{2}$. This affects the fragmentation of emigrants from Bosnia and Herzegovina. Since 2015 the Council of Ministers promises to adopt the Law on the Diaspora. The same initiative also took place in the Republic of Srpska authorities after the first Forum of Diaspora held in February 2018. In early 2018, the Republic of Serbia

1 The Office for Cooperation with the Diaspora and Serbs in the Region. Ministry of Foreign Affairs of thr Republic of Serbia. URL: http://www.dijaspora.gov.rs/en/ (accessed: 27.03.2018).

2 The Sector for Diaspora. Ministry for Human Rights and Refugees. Council of Ministers of Bosnia and Herzegovina. URL: http://www.mhrr.gov.ba/iseljenistvo/aktuelnosti/default.aspx?id = 820\&langTag = bs-BA (accessed: 27.03.2018). 
and the Republic of Srpska launched joint activities in order to adopt the Declaration on the survival of Serbs, which was announced as the basis of the state policy towards Serbs living in a region outside Serbia's borders.

Serbian emigration in Slovenia, with the exception of insufficient financial assistance, was left alone. This situation leads to an accelerated assimilation and the escalation of this population to the majority population. If it is not approached in the systematic way to resolve status of Serbs in Slovenia, which implies systematic and coordinated action at all levels of Serb organization in Slovenia, and the activities of countries of origin of Serbs and the new homeland, the preservation of ethnic identity and culture of Serbs in the Republic of Slovenia will not be of possible.

(C) Medar-Tanjga I., 2018

This work is licensed under a Creative Commons Attribution 4.0 International License

\section{References}

Bešter R. (2009). Pravni okvir, relevanten za integracijo imigrantov v Sloveniji. Razprave in gradivo. Issue 58. Pp. 160-195.

Filipović M. (1970). Srpska naselja u Beloj krajini (u Sloveniji). Radovi. No. XXXV. Pp. 147-238.

Janko Spreizer A. (2006). Avtohtonost v slovenskem narod(nost)nem vprašanju in koncept staroselstva: nastavki za analizo ideologij primata. Razprave in gradivo. Issue 50. Pp. 236-271.

Klopčič V., Komac M., Kržišnik-Bukić V. (2003). Albanci, Bošnjaki, Črnogorci, Hrvati, Makedonci in Srbi v Republiki Sloveniji, Položaj in status pripadnikov narodov nekdanje Jugoslavije v Republiki Sloveniji. Available at: http://www.inv.si/DocDir/Publikacije-PDF/Raziskovalna \%20porocila/ Raziskava_Polozaj_in_status_pripadnikov_narodov_nekdanje_Jugoslavije_v_RS.pdf (accessed: 27.03.2018).

Komac M. (ed.) (2007). Priseljenci - Študije o priseljevanju in vključevanju v slovensko družbo. Available at: http://www.inv.si/DocDir/Publikacije-PDF/2007/KNJIGA.pdf (accessed: 27.03.2018).

Komac M., Medvešek M. (ed.) (2005). Percepcije slovenske integracijske politike. Available at: http:// www.inv.si/DocDir/Publikacije-PDF/2007/KNJIGA.pdf (accessed: 27.03.2018).

Komac M., Medvešek M. (ed.) (2006). Percepcije slovenske integracijske politike. "Uskoško” prebivalstvo $v$ Beli krajini, etnična diskriminacija v delovnem okolju, izseljavanje in povratništvo Slovencev.

Kristen S. (2004). Specialistično proučevanje zakonsko zaščitenih narodnostnih manjšin v Sloveniji do obdobja državne osamosvojitve: zgodovinski pregled. Razprave in gradivo. Issue 45. Pp. 40-81.

Medvešek M., Brezigar S., Bešter R. (2009). Položaj priseljencev in potomcev priseljencev z območja nekdanje Jugoslavije na trgu dela v Sloveniji. Razprave in gradivo. Issue 58. Pp. 24-57.

Roter P. (2008). Spreminjajoči se pomen vsebine kriterijev opredeljevanja (narodnih) manjšin. Razprave in gradivo. Issue 56-57. Pp. 35-68. Inštitut za narodnostna vprašanja, Ljubljana.

Statistical office Republic of Slovenia. http://www.stat.si/StatWeb/en (accessed: 27.03.2018).

Šircelj M. (2003). Verska, jezikovna in narodna sestava prebivalstva Slovenije: popisi 1921-2002. Available at: http://www.stat.si/popis2002/gradivo/2-169.pdf (accessed: 27.03.2018).

The Office for Cooperation with the Diaspora and Serbs in the Region. Ministry of Foreign Affairs of thr Republic of Serbia. http://www.dijaspora.gov.rs/en/ (accessed: 27.03.2018).

The Sector for Diaspora. Ministry for Human Rights and Refugees. Council of Ministers of Bosnia and Herzegovina. http://www.mhrr.gov.ba/iseljenistvo/aktuelnosti/default.aspx?id=820\&langTag = bs-BA (accessed: 27.03.2018). 
Žagar M. (2006). Etnični odnosi, nacionalizem, manjšine in človekove pravice v jugovzhodni Evropi in v evropskih okvirih. Razprave in gradivo. Issue 50. Pp. 286-297.

Башић Г. (2005). Европски стандарди и положај српске мањине. Научни скупови САНУ. Book CIX. Pp. 65-90.

Ивић А. (1923). Миграције Срба у Хрватску током 16, 17. и 18. стољећа. Available at: https://www. zapadnisrbi.com/images/PDF/Migracije-Srba-u-Hrvatsku-tokom-16-17-i-18-stoleca-AleksaIvic.pdf (accessed: 27.03.2018).

Комац М. (2000). Српска заједница у Словенији, Беседа - Часопис за културу. No. 1. Year I. Pp. 7-33.

Кораћ Ж. (2005). Историјске и нове мањине - Етничка дистанца - Конституисање државематице. Научни скупови САНУ. Book CIX. Pp. 505-508.

Мал Ј. (1924). Ускочке сеобе и словенске покрајине - повест насеобина с културно-историјским приказом.

Становчић В. (2005). Заштита мањина као основа за бригу о дијаспори. Научни скупови САНУ. Book CIX. Pp. 31-64.

\title{
Article history:
}

Received: 30 May 2018

Revised: 27 July 2018

Accepted: 20 October 2018

\section{For citation:}

Medar-Tanjga I. (2018) Ethno-demographic position of Serb population in Republic of Slovenia after the dissolution of former Yugoslavia. RUDN Journal of Economics, 26(4), 674-684. DOI: $10.22363 / 2313-2329-2018-26-4-674-684$

\section{Bio Note:}

Irena Medar-Tanjga, PhD in Geography, Associate Professor, Department of Geography, Faculty of Sciences, University of Banja Luka. Contact information: e-mail: irena.medar-tanjga@pmf. unibl.org

\section{Этнодемографическая позиция сербского населения в Республике Словения после распада бывшей Югославии}

\author{
И. Медарь-Танга \\ Университет Баня-Луки \\ Республика Сербская, Босния и Герцеговина, 78000, Баня-Лука, Младен Стоянович, 2
}

Проблема сербского населения в Республике Словения является парадигмой всех проблем, возникших в связи с распадом Социалистической Федеративной Республики Югославии. Политические и географические процессы во время этого распада привели к созданию новых политических и территориальных субъектов со значительно изменившимися условиями этнокультурного и этнодемографического развития. Сербы, которые жили в стране, сейчас являются диаспорой с ограниченными институциональными рамками развития. Современная этнодемографическая позиция сербов в Словении обусловлена многочисленными региональ- 
ными (балканскими) и локальными детерминантами. Количество сербов, территориальное расположение, их понимание этнической принадлежности, взаимоотношения внутри общины, отношения со страной, в которой они живут, отношения с государствами, из которых они происходят - все это важные элементы их жизни в Словении. Их положение различалось в зависимости от исторической эпохи и требовало различных форм действий для сохранения этнической идентичности сообщества. Сегодня сербы в Словении лишились избирательного округа и равенства столкнулись с невежеством и искоренением. Они официально не признаны меньшинством, хотя существование общины коренного населения в Бела-Краине представляет собой историческую основу для повышения их статуса. Статус меньшинства очень важен, однако для сохранения и развития национальной и культурной самобытности не является решающим, поскольку помимо правовых норм для сохранения идентичности каждого меньшинства необходимы стабильные и благоприятные социальные и политические условия.

Ключевые слова: сербское население, Республика Словения, этнодемографическая позиция, население, географическое распределение, статус

\section{История статьи:}

Дата поступления в редакцию: 30 мая 2018

Дата проверки: 27 июля 2018

Дата принятия к печати: 20 октября 2018

\section{Для цитирования:}

Медарь-Танга И. Ethno-demographic position of Serb population in Republic of Slovenia after the dissolution of former Yugoslavia (Этнодемографическая позиция сербского населения в Республике Словения после распада бывшей Югославии) // Вестник Российского университета дружбы народов. Серия: Экономика. 2018. Т. 26. № 4. C. 674-684. DOI: 10.22363/2313-2329-2018-26-4-674-684

\section{Сведения об авторе:}

Медарь-Танга Ирена, кандидат географических наук, доцент кафедры географии, факультет естественных наук, Университет Баня-Луки (Республика Сербская, Босния и Герцеговина). Контактная информация: e-mail: irena.medar-tanjga@pmf.unibl.org 